Article

\title{
Improving Infrastructure Installation Planning Processes using Procedural Modeling
}

\author{
Nae-Young Choei ${ }^{1}$, Hyungkyoo Kim ${ }^{1}\left[\right.$ and Seonghun Kim ${ }^{2, *}$ \\ 1 Department of Urban Design and Planning, Hongik University, Seoul 04066, Korea; \\ nychoei@hongik.ac.kr (N.-Y.C.); hkkim@hongik.ac.kr (H.K.) \\ 2 Research Institute of Science and Technology, Hongik University, Seoul 04066, Korea \\ * Correspondence: monotaxism@gmail.com; Tel.: +82-2-320-1635
}

Received: 6 January 2020; Accepted: 6 February 2020; Published: 10 February 2020

check for updates

\begin{abstract}
Time and costs are often the most critical constraints in implementing a development impact fee (DIF) for local infrastructure installation planning in South Korea. For this reason, drafting quality plan alternatives and calculating precise DIFs for improvement remain challenging. This study proposes an application of a procedural modeling method using CityEngine as an alternative to traditional methods, which rely on AutoCAD. A virtual low-density suburban development project in Jeju, South Korea was used to compare the workability of the two methods. The findings suggest that procedural modeling outperforms the other approach by significantly reducing the number of steps and commands required in the planning process. This paper also argues that procedural modeling provides real-time 2- and 3-dimensional modeling and design evaluation and allows for a more efficient assessment of plan quality and calculation of DIF. We also argue for the need to diffuse procedural modeling to better support local planning practices.
\end{abstract}

Keywords: infrastructure installation planning; procedural modeling; development impact fees; Jeju

\section{Introduction}

The growth of cities and regions requires planning practices to address the increasing demand for infrastructure. Supplying infrastructure is a service usually provided by central and local governments [1]. One frequently observed issue in infrastructure supply is that the cost of installation is a burden on the public sector, while the benefits are seized by a handful of individuals [2-5]. This generates a problem of equity. In response, many local governments in the United States combine development permit issues with development impact fees (DIF) as a betterment levy. DIF is a policy instrument used to control urban growth [6,7] and is recognized by many critics as a reasonable action of police power to promote equity [8,9] by imposing an installation cost of the infrastructure for new developments, theoretically equivalent to the social marginal cost, on the developers and householders. Today, DIF has triggered lively debates on housing prices, housing supply, and regional economic growth [10-20], as well as on its environmental contributions, such as restricting vehicle use and reducing air pollution levels [14,21-23].

Unsustainablity is found in many suburban developments [24-28]. For this reason, infrastructure installation planning in South Korea mandates the imposition of DIF. Following a four-stage process (Figure 1), local governments calculate DIF-based infrastructure installation plans by relating capital development plans and infrastructure cost allocation plans or by applying coefficients like the land conversion factor in limited circumstances. These plans attempt to balance development permits with the provision of infrastructure and to levy a part of the costs of installation to developers [29,30]. DIF in South Korea faces several issues that need to be resolved, as argued by local critics. Institutional and legal settings are criticized for lacking consistency [31]. The arbitrary designation of infrastructure 
supply zones, for example, is questioned [32-36]. Other concerns include double taxation issues and bubble effects [31].

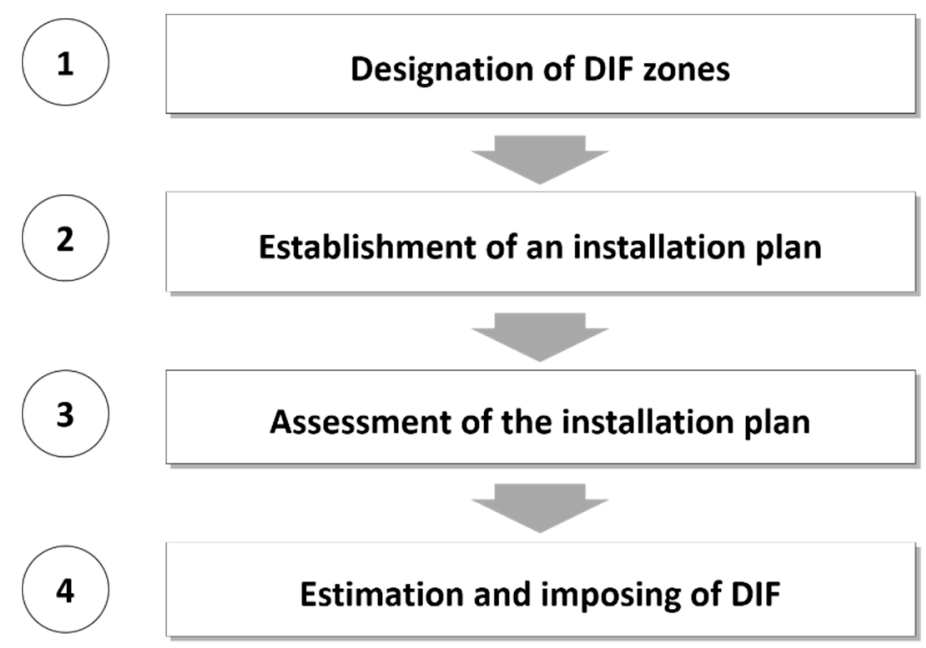

Figure 1. The four stages of infrastructure installation planning in South Korea.

One clearly overlooked aspect in the literature, especially in the South Korean context, is the applicability of DIF in local planning practice. Time and cost are often the most critical concerns in implementing DIF in infrastructure installation planning, though it is difficult to find empirical studies that investigate this. Typically, zoning requirements are automatically cleared if a plan is not established within a year after going through public hearings and planning commission meetings. We found, from a series of interviews with local planners and practitioners, that their work efficiency and consistency are often challenged when drafting plan alternatives and calculating precise DIFs; these problems require major improvements. For these reasons, with a specific focus on the infrastructure installation planning process, we propose the application of procedural modeling using CityEngine in the planning process as an alternative to the existing method for calculating DIF, which relies on AutoCAD, to enhance workability. We do so by applying the traditional method and procedural modeling to a virtual single-family housing development project in Jeju, South Korea. We compare the work processes of the two methods and identify the benefits of the latter by investigating the detailed steps and commands required for each method. The findings of the research may inform planners and policymakers at the local levels.

\section{Procedural Modeling}

Technologies heavily used in planning, like computer-aided design (CAD) and the geographic information system (GIS), have significantly enhanced efficiency in practice but retain limitations. In practice, these two tools require the extensive drawing of objects in the plan. These drawings are produced manually using a computer mouse of tablet pencil. On the other hand, procedural modeling provides distinct advantages. It automatically generates and updates 3-dimensional models of urban environments by incorporating information on roads, blocks, buildings, and other physical elements in real-time.

In general, procedural modeling refers to a computer graphics technology that automatically implements a completion model from spatial and attribute information with a set of rule files, similar to the use of grammar in linguistics. This methodology has already been used in many 3-dimensional modeling programs, including 3ds Max, Blender, Cinema 4D, and OpenSCAD. CityEngine is one of the many applications that apply procedural modeling [37] based on shape grammar [38]. It is widely accepted as an effective tool in designing and implementing street patterns and subdivision plans for a given site during the initial states of urban development. 
Shape grammar, introduced by Stiny and Gips, is a type of grammatical system that generates geometric figures and spaces [39]. It focuses on interpreting orders through which a complex shape can be delineated with a group of simple shapes, just as sentences, paragraphs, and texts are ultimately produced by combining individual words using grammar. The composition of a shape grammar is built upon an initial form to be transformed; a group of shape rules, which define the initial form transformation; and a generation engine for selecting and executing the shape rules. Efforts to apply shape grammar to realistic modeling works have long been carried out in a wide range of industrial fields like architecture and urban planning [40-44], coffee makers [45], and Harley-Davidson motorcycles [46].

Procedural modeling is based on the theoretical basis of the L-System, derived from biology [37] and first introduced by Lindenmayer [47]. This system is capable of simultaneously generating new forms from each initial form [47] and could be useful for modeling an organism such as a tree, because the tree's genesis and growth in all directions are accurately and simultaneously explained by this theory. Procedural modeling perceives the city as an organism, in which elements such as buildings, roads, and parcels are intertwined. Recent studies of procedural modeling (mostly by computer graphics engineers) have focused on various elements of the city, like topography [48,49], vegetation [50-52], water systems [53,54], roads, buildings [37,55], building interiors, and the overall urban systems [56].

\section{A Virtual Development Project}

Jeju is geographically the largest island in South Korea located in the south of the Korean Peninsula, as presented in Figure 2, and is a special self-governing administrative unit. Although the island is globally recognized as an area with high environmental values $[57,58]$, its coastal waters and soil are being severely damaged by pollution $[59,60]$ because of the growing amount of discharged wastewater that often exceeds the island's treatment capacity [61]. The indiscriminate allowance of new real estate developments with little concern for existing capacities has been criticized as one of the key reasons behind these issues [62-64]. Raising general utility rates due to new suburban residential developments is triggering serious equity debates among the residents [65].
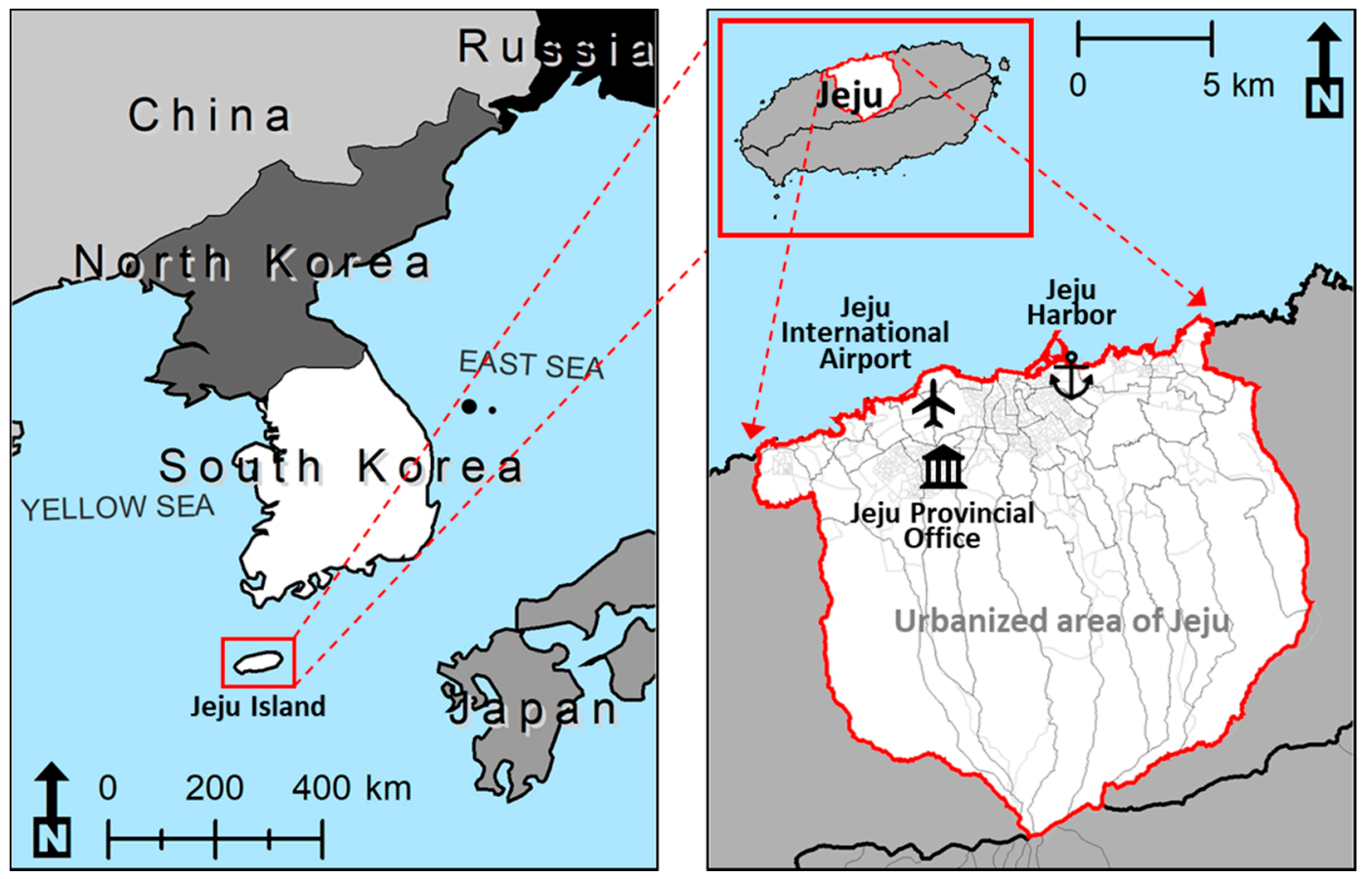

Figure 2. The location of Jeju. 
Figure 3 presents the site in Jeju selected for our virtual development project. In recent years, a number of development permits have been issued in the site, and new arterial roads have been constructed along its outskirts. Designating the site as a DIF zone may generate revenue and thereby secure a relevant supply of infrastructure. For research purposes and to simulate the outcomes of various plans, we assume that the site remains undeveloped.
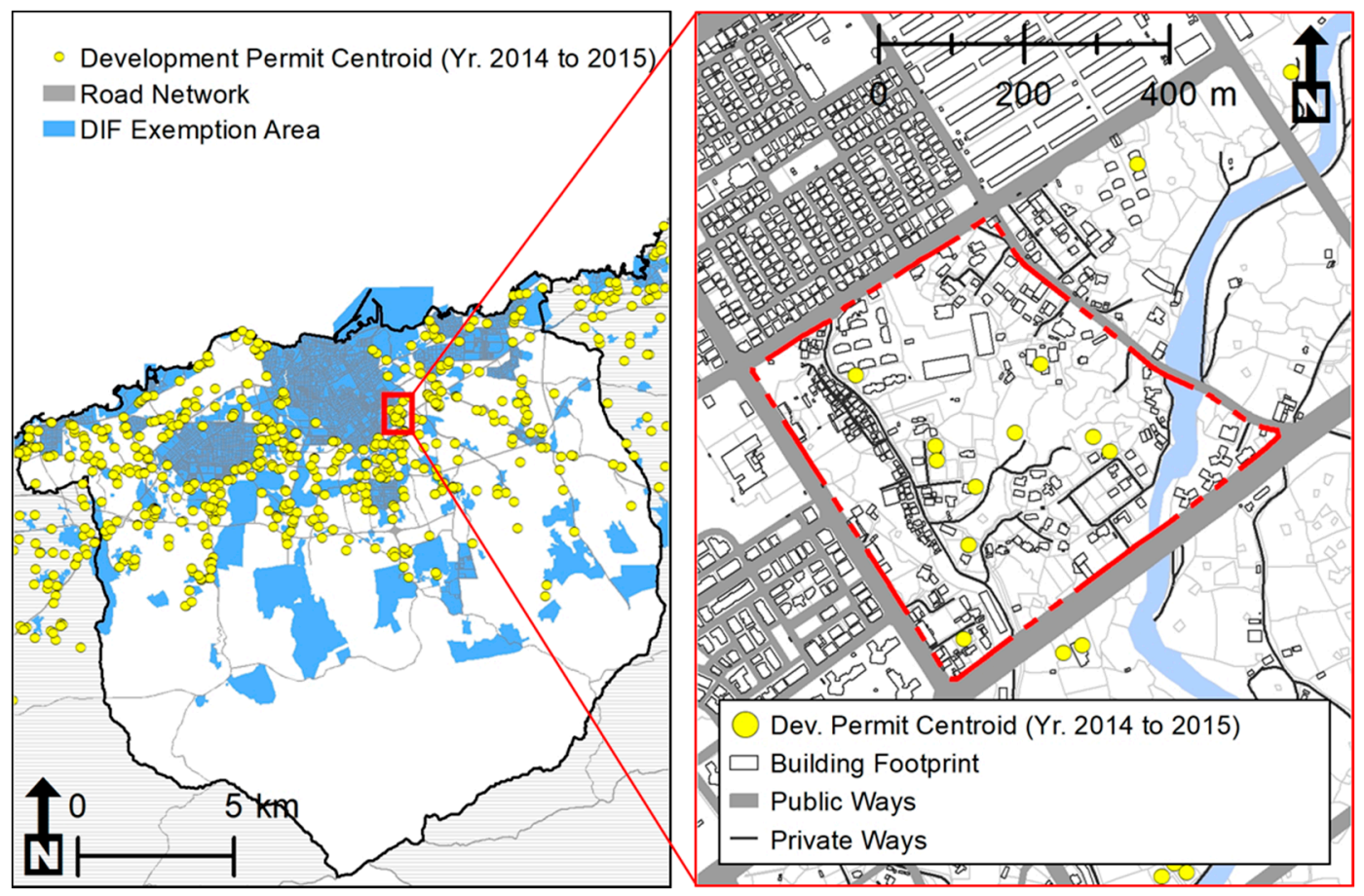

Figure 3. Location of the site for the virtual development project.

We utilize a wide range of information on topography, buildings, roads, parcels, and land prices, which are regularly gathered and updated by government agencies. The information on topography includes digital elevation maps and orthophotos. Information on buildings and roads was retrieved from geospatial vector data. Data for the parcels and their prices are from 2013.

A set of conditions is assumed for installing the infrastructure for this virtual development. Given the recent urban development trends in Jeju, we assume a low-density residential development that accommodates around 450 single-family detached houses at a density level of a 2.0 floor area ratio (FAR) and a 0.6 building coverage ratio (BCR), following local zoning requirements. The proportion of land allocated for roads is confined to between $15 \%$ and $30 \%$, which is also based on the zoning requirements.

Six development typologies that employ the findings of Southworth and Owens [66] were established for the project, as shown in Figure 4. The first three are (1) grid, (2) loop, and (3) cul-de-sac; and the other three are combinations of the first three, which are (4) grid and loop, (5) loop and cul-de-sac, and (6) cul-de-sac and grid. As the site is located on a plain, we do not take into account local features (such as topography, conservation areas, or flood prone areas) in this process, although these features may be incorporated in procedural modeling practice when necessary. Table 1 outlines the site characteristics of the six typologies. 


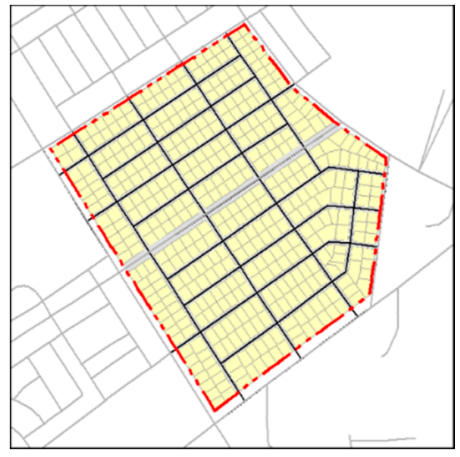

Grid

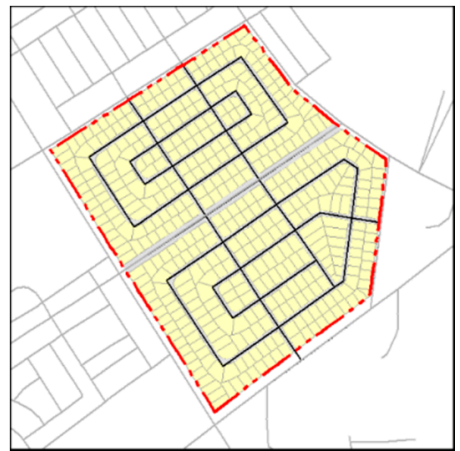

Grid and Loop

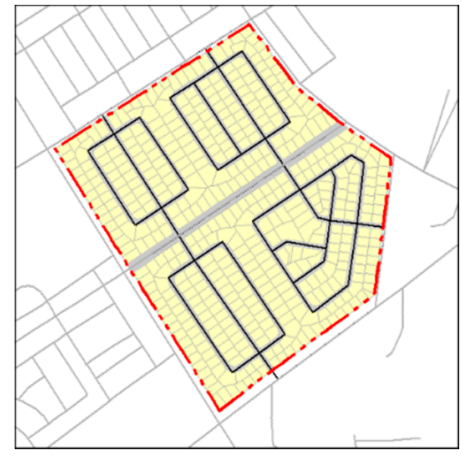

Loop

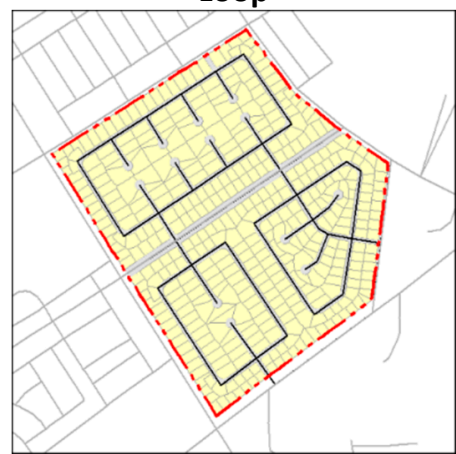

Loop and Cul-de-sac

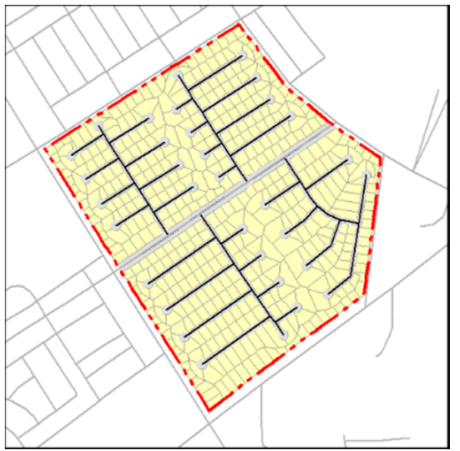

Cul-de-sac

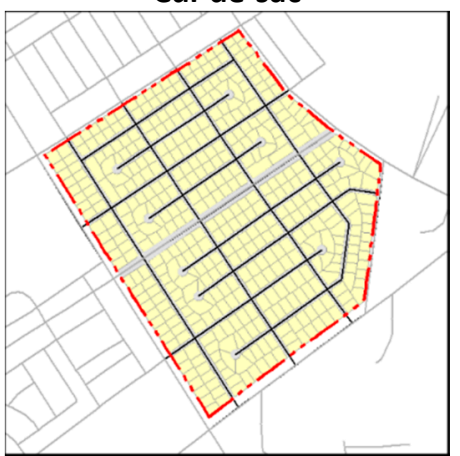

Cul-de-sac and Grid

Figure 4. The six development typologies adopted in the virtual development project.

Table 1. Site characteristics of the six typologies.

\begin{tabular}{ccccccc}
\hline Site Characteristics & Grid & Loop & Cul-de-sac & $\begin{array}{c}\text { Grid and } \\
\text { Loop }\end{array}$ & $\begin{array}{c}\text { Loop and } \\
\text { Cul-de-sac }\end{array}$ & $\begin{array}{c}\text { Cul-de-sac } \\
\text { and Grid }\end{array}$ \\
\hline Site area $\left(\mathrm{m}^{2}\right)$ & 208.332 & 208.332 & 208.332 & 208.332 & 208.332 & 208.332 \\
Total area of parcels $\left(\mathrm{m}^{2}\right)$ & 164,823 & 172,615 & 171,321 & 171,764 & 172,787 & 166,895 \\
Total number of parcels & 457 & 477 & 487 & 463 & 434 & 460 \\
Total area of roads $\left(\mathrm{m}^{2}\right)$ & 43,510 & 35,717 & 37,011 & 36,569 & 35,546 & 41,438 \\
Total length of roads $(\mathrm{m})$ & 5414 & 4299 & 3770 & 4425 & 3972 & 4941 \\
$\quad \%$ area of roads & 20.9 & 17.1 & 17.8 & 17.6 & 17.1 & 19.9 \\
$\begin{array}{c}\text { Total length of water and } \\
\text { sewage }(\mathrm{m})\end{array}$ & 5414 & 4299 & 3770 & 4425 & 3972 & 4941 \\
\hline
\end{tabular}

Table 2 presents the rules and definitions of the six metrics in the two categories we adopted for a comparative evaluation of the six typologies. First, we apply three metrics to measure the quality of living for each typology: (1) isovist to reflect safety [67]; (2) integration to assess the legibility of the residential environment [68]; and (3) betweenness to judge comfort [69]. Second, we adopt measures of costs for road construction, water and sewage supply, and the compensation of land to install infrastructure. Their formulae follow local codes.

Table 3 presents calculation results of the quality of development for the six typologies. The cul-de-sac and grid typologies showed the highest isovist values, followed by grid, grid and loop, loop, loop and cul-de-sac, and cul-de-sac. For integration, grid shows the highest value, followed by cul-de-sac and grid, grid and loop, loop, cul-de-sac, and loop and cul-de-sac. Cul-de-sac and grid again present the highest betweenness, followed by grid, grid and loop, cul-de-sac, loop and cul-de-sac, and loop. Overall, the cul-de-sac and grid typology yields the best quality among the six.

Table 4 shows the calculated results of the infrastructure installation costs and expected DIF for each development typology. The total installation cost is topped by the grid, followed by loop and cul-de-sac, cul-de-sac and grid, grid and loop, cul-de-sac, and loop. The expected total DIF equals 30\% of this total cost based on the local infrastructure supply codes. In the end, the largest expected total 
DIF per household is found for the loop, followed by cul-de-sac, grid and loop, cul-de-sac and grid, loop and cul-de-sac, and grid.

Table 2. Metrics and their rules of definitions for measurements.

\begin{tabular}{|c|c|c|}
\hline \multicolumn{2}{|c|}{ Metrics } & Rules or Definitions \\
\hline \multirow{3}{*}{$\begin{array}{l}\text { Quality of the development } \\
\text { typology }\end{array}$} & Isovist [67] & $\begin{array}{l}\text { Mean amount of areas visible from a } \\
\text { specific location }\end{array}$ \\
\hline & Integration [68] & $\begin{array}{l}\qquad I N T_{i}=\frac{D_{N}}{R A_{i}} \\
\text { where } I N T_{i} \text { is integreation of street } i ; D_{N} \text { is a } \\
\text { normalizing factor depending on } N \text {; and } R A_{i} \\
\text { is relative asymmetry }\end{array}$ \\
\hline & Betweenness [69] & $\begin{array}{l}\qquad B(v)=\sum_{w} \sum_{u} \frac{g_{u w}(v)}{g_{u w}} \\
\text { where } B(v) \text { is betweenness at node } v ; u \text { is trip } \\
\text { origin; } w \text { is trip destination; } g_{u w} \text { is the number } \\
\text { of paths between } u \text { and } w \text {; and } g_{u w}(v) \text { is the } \\
\text { number of paths between } u \text { and } w \text { that } \\
\text { contain node } v \text {. }\end{array}$ \\
\hline \multirow{3}{*}{ Installation Costs } & $\operatorname{Road}^{a}$ & $\begin{array}{l}\text { (total road length) } \times \text { (cost per meter)/(total } \\
\text { area of residential parcels) }\end{array}$ \\
\hline & Water and sewage ${ }^{a}$ & $\begin{array}{l}\text { (total water and sewage length) } \times \text { (cost per } \\
\text { meter)/(total area of residential parcels) }\end{array}$ \\
\hline & Land compensation ${ }^{a}$ & $\begin{array}{c}\text { (total price of parcels acquired for road } \\
\text { construction)/(total area of residential parcels) }\end{array}$ \\
\hline
\end{tabular}

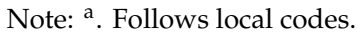

Table 3. Calculation of the quality of development for each typology and their min-max normalized values.

\begin{tabular}{|c|c|c|c|c|c|c|c|}
\hline \multicolumn{2}{|c|}{ Metrics } & Grid & Loop & Cul-de-sac & $\begin{array}{l}\text { Grid and } \\
\text { Loop }\end{array}$ & $\begin{array}{l}\text { Loop and } \\
\text { Cul-de-sac }\end{array}$ & $\begin{array}{l}\text { Cul-de-sac } \\
\text { and Grid }\end{array}$ \\
\hline \multirow{6}{*}{$\begin{array}{c}\text { Quality of the } \\
\text { development } \\
\text { typology }\end{array}$} & \multirow{2}{*}{ Isovist } & 7381 & 7041 & 6601 & 7283 & 6964 & 7473 \\
\hline & & 0.97 & 0.27 & 0.00 & 0.89 & 0.11 & 1.00 \\
\hline & \multirow{2}{*}{ Integration } & 5943 & 5124 & 5139 & 5617 & 4818 & 5927 \\
\hline & & 1.00 & 0.06 & 0.07 & 0.06 & 0.00 & 1.00 \\
\hline & \multirow{2}{*}{ Betweenness } & 941,300 & 175,119 & 465,663 & 827,554 & 254,803 & 958,839 \\
\hline & & 0.99 & 0.00 & 0.17 & 0.94 & 0.01 & 1.00 \\
\hline \multicolumn{2}{|c|}{ Mean normalized value } & 0.99 & 0.11 & 0.08 & 0.63 & 0.04 & 1.00 \\
\hline \multicolumn{2}{|c|}{ Rank } & 2 & 4 & 5 & 3 & 6 & 1 \\
\hline
\end{tabular}

Table 4. Calculation of installation costs and expected development impact fee (DIF) for each typology.

\begin{tabular}{|c|c|c|c|c|c|c|c|}
\hline \multicolumn{2}{|c|}{ Metrics } & \multirow{2}{*}{$\begin{array}{l}\text { Grid } \\
5050\end{array}$} & \multirow{2}{*}{$\begin{array}{c}\text { Loop } \\
4146\end{array}$} & \multirow{2}{*}{$\begin{array}{c}\text { Cul-de-sac } \\
4296\end{array}$} & \multirow{2}{*}{$\begin{array}{c}\begin{array}{c}\text { Grid and } \\
\text { Loop }\end{array} \\
4245\end{array}$} & \multirow{2}{*}{$\begin{array}{c}\begin{array}{c}\text { Loop and } \\
\text { Cul-de-sac }\end{array} \\
4126\end{array}$} & \multirow{2}{*}{$\begin{array}{c}\begin{array}{c}\text { Cul-de-sac } \\
\text { and Grid }\end{array} \\
4810\end{array}$} \\
\hline Installation & Road & & & & & & \\
\hline $\begin{array}{l}\text { costs (million } \\
\text { KRW) }\end{array}$ & $\begin{array}{l}\text { Water and } \\
\text { sewage }\end{array}$ & 1560 & 1239 & 1087 & 1275 & 1145 & 1424 \\
\hline & $\begin{array}{c}\text { Land } \\
\text { compensation }\end{array}$ & 9603 & 7491 & 7962 & 7948 & 9106 & 7693 \\
\hline \multicolumn{2}{|c|}{$\begin{array}{l}\text { Total installation cost (million } \\
\text { KRW) }\end{array}$} & 16,214 & 12,876 & 13,345 & 13,468 & 14,377 & 13,926 \\
\hline \multicolumn{2}{|c|}{$\begin{array}{l}\text { Expected Total DIF } \\
\text { (million KRW) }\end{array}$} & 4864 & 3863 & 4003 & 4040 & 4313 & 4178 \\
\hline \multicolumn{2}{|c|}{$\begin{array}{l}\text { Expected DIF per household } \\
\text { (million KRW) }\end{array}$} & 10.6 & 8.1 & 8.2 & 8.7 & 9.9 & 9.1 \\
\hline \multicolumn{2}{|c|}{ Rank } & 6 & 1 & 2 & 3 & 5 & 4 \\
\hline
\end{tabular}




\section{Comparing the Two Methods of Infrastructure Installation Planning}

\subsection{The Traditional Method and Procedural Modeling}

Two methods of infrastructure installation planning are possible to implement in the virtual project, as Figure 5 illustrates. One is the traditional method that uses AutoCAD to model the project, depthmapX to assess the development quality, and ArcGIS to calculate the DIF. The other is based on procedural modeling using CityEngine as a substitute for AutoCAD. depthmapX and ArcGIS are used for the same purposes.

\section{Traditional method \\ Procedural modeling}
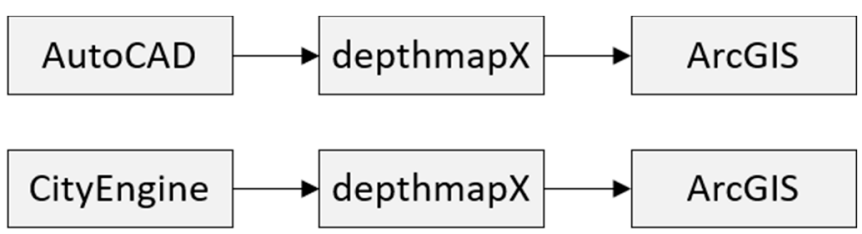

Figure 5. Two methods of infrastructure installation planning.

Figure 6 illustrates in detail the two methods for infrastructure installation planning. The traditional method follows an eight-step process. The first step, data acquisition, involves collecting and cleaning the data, typically for the built environment, zoning, topography, and land prices. The next step is to draft a schematic plan that illustrates a rough image of the development using the data. The third step models the 2-dimensional features of the plan, such as the road networks, blocks, building footprints, and infrastructures, using AutoCAD. The fourth step models the 3-dimensional features, including the topography, buildings, vegetation, and elevations of various infrastructures. This is also done by AutoCAD and provides a glimpse of the pedestrian (or a bird's eye view) of the plan. The fifth decides whether the plan is acceptable based on the planner's expertise and experience. If the plan is considered unacceptable, a new schematic plan is drafted from step two. The sixth step involves pre-processing the model by AutoCAD prior to the spatial analysis. The amount of work in this step depends on the compatibility of the model and the availability of the attribute data. The seventh step carries out a spatial analysis of the plan using depthmapX, a spatial syntax tool, and ArcGIS. The former is applied to measure plan quality and the latter to calculate the installation costs and DIF. The eighth is carried out by an expert planner by determining the plan's feasibility through an assessment of the plan's quality, installation costs, and DIF. A candidate plan is completed after these eight steps. If the plan is perceived to be unfeasible, a new schematic plan is drafted from step two.

Procedural modeling using CityEngine goes through six steps, which is two steps shorter than the traditional method. The first step simultaneously prepares a rule file and spatial analysis tool. The rule file plays a critical role by creating models and providing their appearances in detail. A substantial amount of time and costs may be required to develop coding syntax to generate models and to build assets, such as buildings and road textures. The amount can be significantly reduced when the rule file is reused or imported from external sources. The spatial analysis tool is a set of codes that are customized for procedural modeling; they are created by ModelBuilder in ArcGIS and are interoperable with the rule file. The second step, data acquisition, and the third, schematic plan, are identical to those from the traditional method. The fourth step involves 2- and 3-dimensional modeling done simultaneously in CityEngine. This is combined with a real-time evaluation of plans by an expert planner. The fifth step, spatial analysis using depthmapX and ArcGIS, and the sixth, which determines the project's feasibility by assessing plan quality, installation costs, and DIF, are again the same as those involved in the previous method. The candidate plan is finalized after these six steps. 

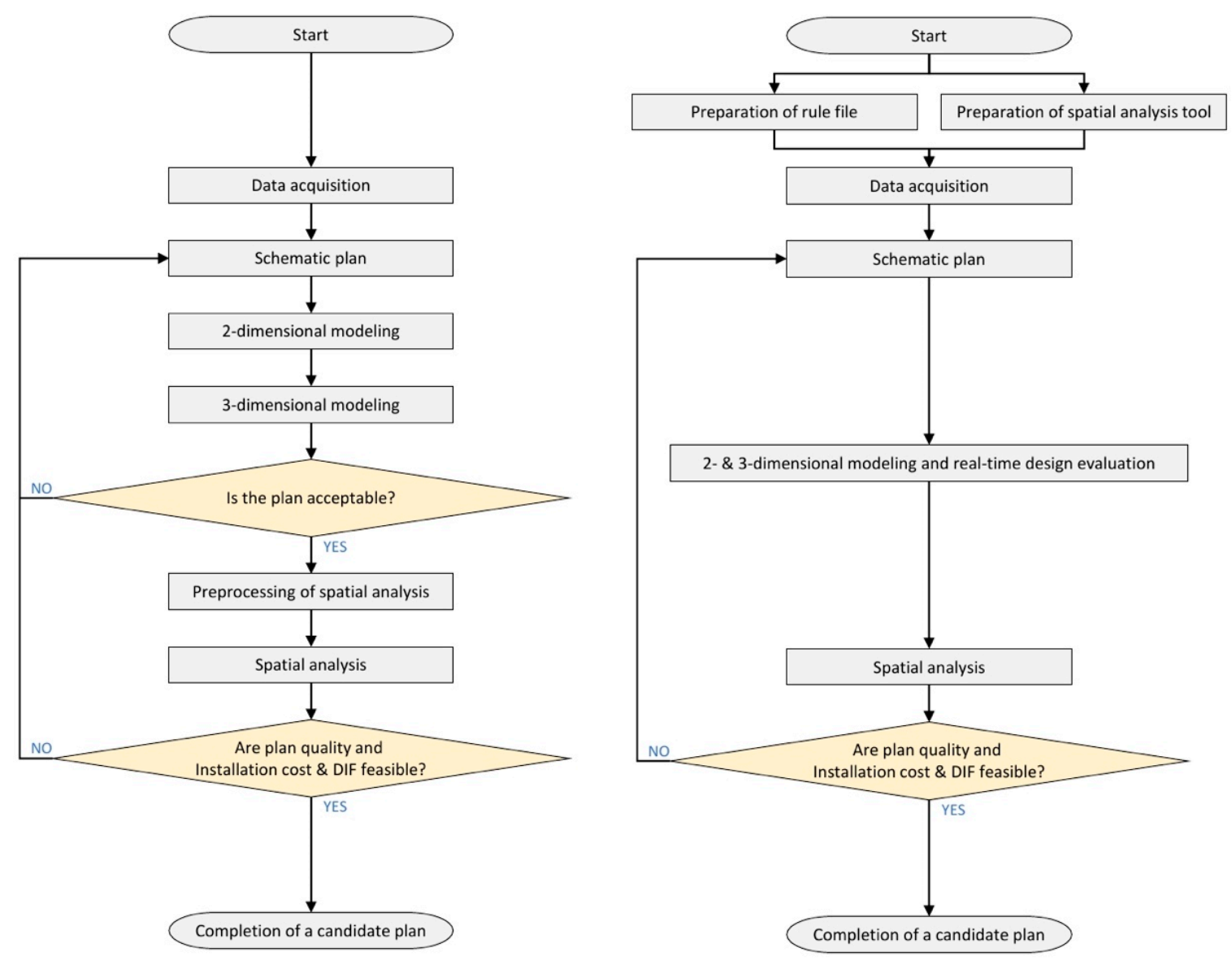

Figure 6. The two methods of infrastructure installation planning in detail: (left) traditional method; and (right) procedural modeling.

\subsection{Benefits of Procedural Modeling Using CityEngine}

Besides the number of steps required for the two methods of infrastructure installation planning, there are a number of differences that distinguish the two from each other. First, the new method initially requires an additional step for preparation. Second, the modeling process of the two is significantly different; 2- and 3-dimensional modeling, and their initial assessment, in the traditional method are combined into a single step in the new method. Third, the preprocessing of spatial analysis in the traditional method is omitted in the new method, as it is already taken care of in the initial preparation step.

The disadvantages of using procedural modeling can be summarized as follows. First, the time and cost involved in the initial preparation step can be unavoidable, especially when creating a rule file and spatial analysis tool for the first time. Second, advanced and specialized skills may be required to carry out this step. However, the time and cost will gradually diminish when the step is repeated multiple times. Further, the skills can be adopted without a steep learning curve.

There are clear advantages in procedural modeling. Simultaneous modeling of 2- and 3-dimensions enables real-time assessment of the draft plan, thereby considerably reducing the time and cost in the planning process to calculate the DIF. Second, the interoperability between CityEngine, depthmapX, and ArcGIS is significantly enhanced to remove the preprocessing step and avoid data loss during the spatial analysis.

One example of the benefits of procedural modeling is the automated editing of features. As shown in Figure 7, the traditional procedure usually goes through the following eight steps and ultimately requires 307 separate commands when constructing a road that cuts through an existing residential block: 
1. Draw a center line to define the origin, destination, orientation, and shape of the new road feature;

2. Secure some buffer space to edit the feature;

3. Develop a rough draft of the feature in the secured space;

4. Complete design of feature details, such as nodes (i.e., intersections) and street corners;

5. Convert the remaining parts of the buffer space to residential use;

6. Dissolve the parts into adjacent residential blocks;

7. Subdivide the updated residential blocks;

8. Recalculate and assign attribute values to road and parcel features.

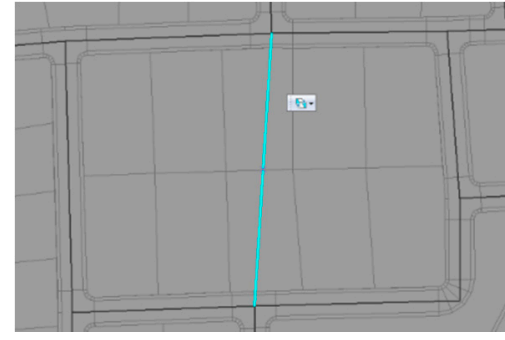

Step 1.

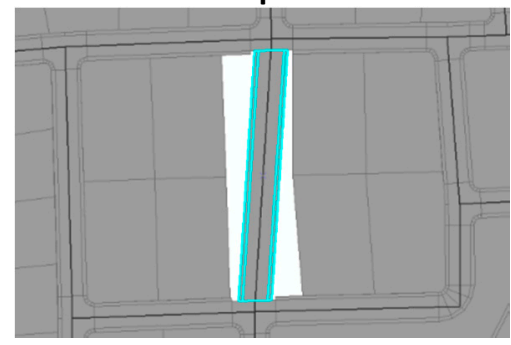

Step 3.

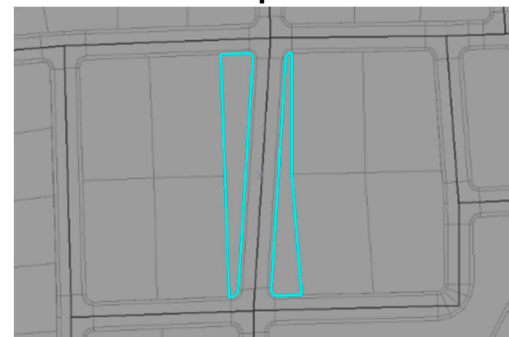

Step 5.

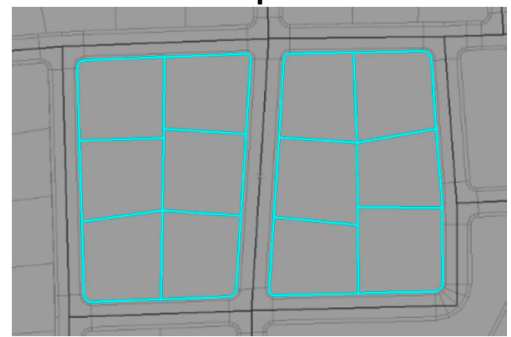

Step 7.

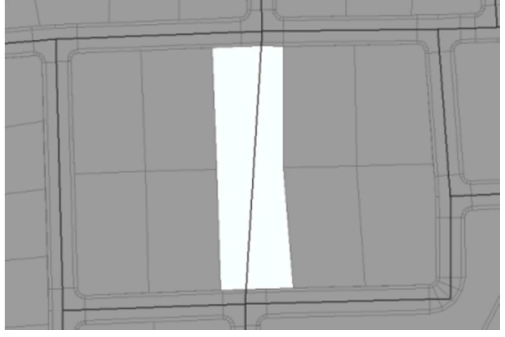

Step 2.

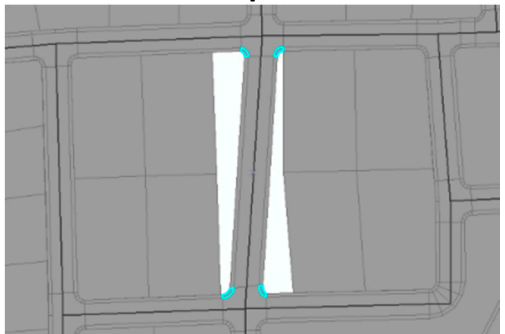

Step 4.

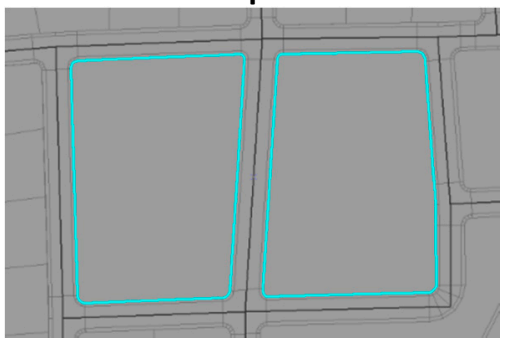

Step 6.

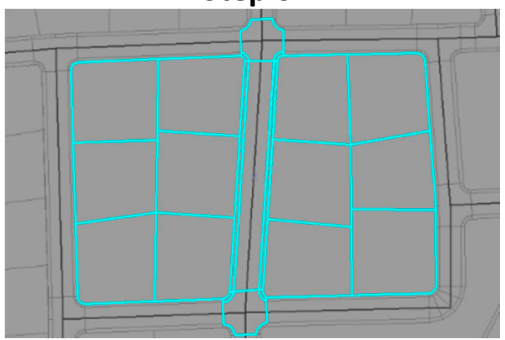

Step 8.

Figure 7. The existing procedure for installing a new road.

CityEngine, on the other hand, requires only the first step of the traditional procedure, which is composed of only two commands. The details and attribute values of the road feature are processed by automatically assuming that the environmental variables are input into the model beforehand. This significantly shortens the modeling process by reducing the number of steps from eight, as previously illustrated, to one, as shown in Figure 8. 

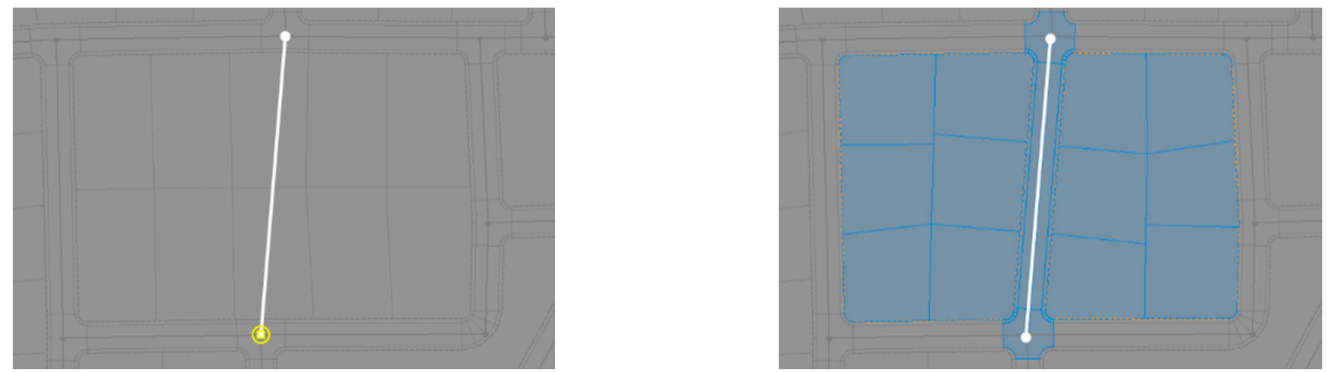

Figure 8. An alternative procedure for installing a new road using CityEngine.

The benefits of using procedural modeling do not stop here. As Figure 9 illustrates, CityEngine creates real-time 3-dimensional models using the default values embedded in a rule file or feature attributes that exist in a 2-dimensional model, when the rule file is applied. Figure 8 itself completes a modification of the 3-dimensional model. This significantly shortens the modeling process, as well as the time and cost required. It also provides a modification of the plan alternatives and offers chances to visually review the results at the same time. On the other hand, the traditional method results in a significant increase in time and cost as it does not allow 2-dimensional modeling, 3-dimensional modeling, and plan reviews take place simultaneously.
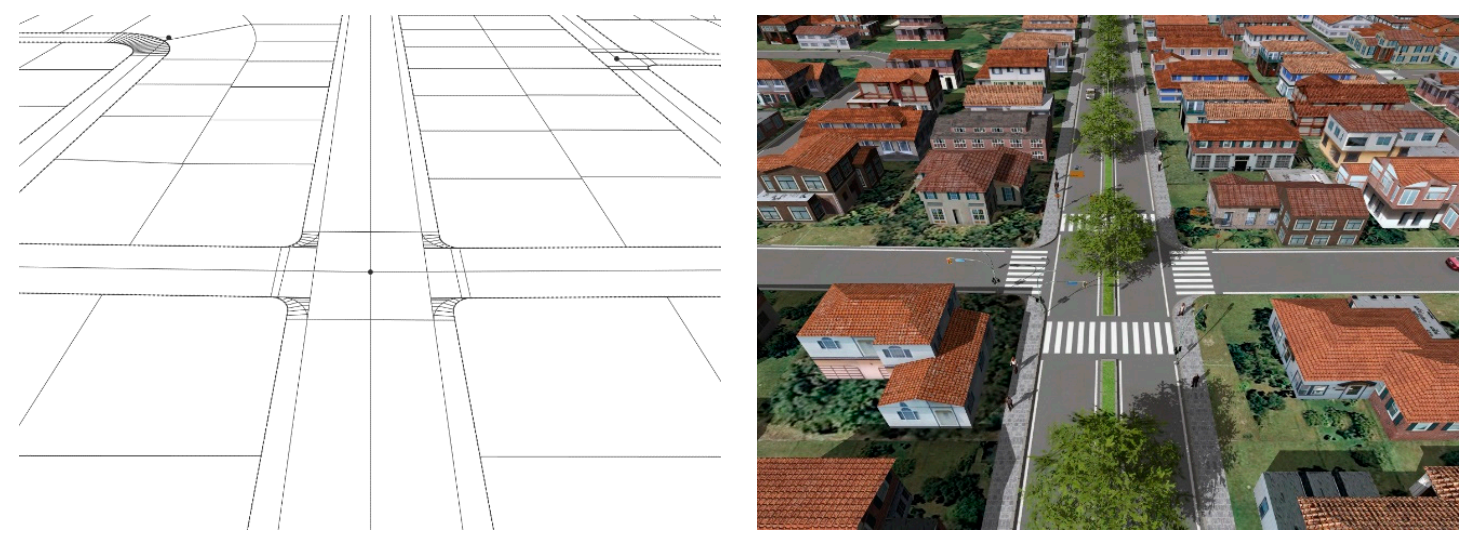

Figure 9. An example of the automated installation of roads using a rule file in procedural modeling.

The preparation of rule files and spatial analysis tools may make procedural modeling more time and cost heavy than the traditional method. However, the time and cost spent on preparation are usually no more than a one-time expense. Rule files and spatial analysis tools, either created or acquired, can be re-applied to other projects without any additional work. Figure 10 presents this process.

From a long-term perspective, procedural modeling presents more efficient performance than the traditional method, as Figure 11 illustrates. The traditional method may reduce time and cost in the initial stages of the project. However, as more plan alternatives are developed and reviewed, procedural modeling increasingly outperforms the other. The benefits of the traditional method are likely to diminish for the following reasons. First, procedural modeling is capable of drafting 2and 3-dimensional models and carrying out reviews simultaneously. Second, it does not require the preprocessing of spatial analysis. Third, the time and cost required for preparing rule files and spatial analysis tools do not occur repeatedly. 
(a)

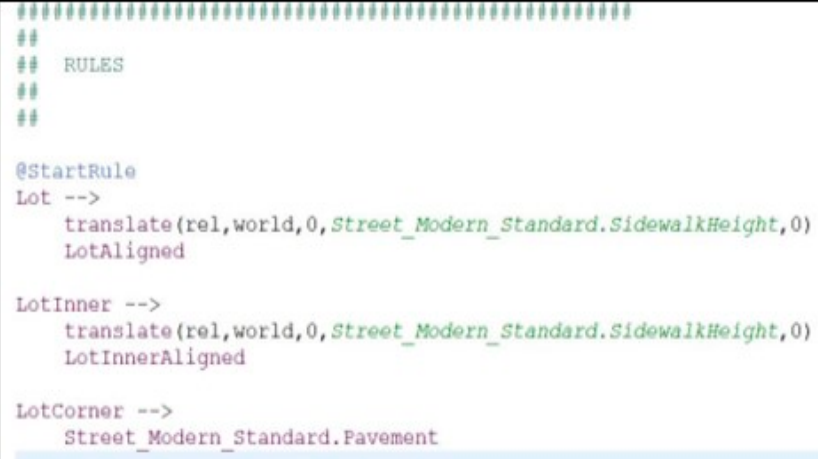

(b)

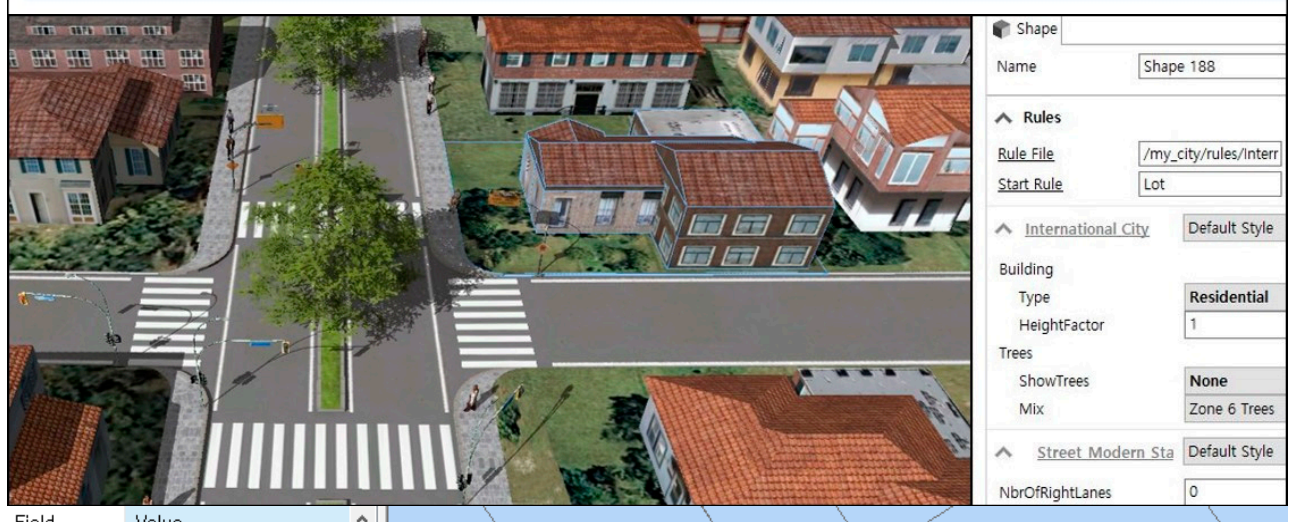

(c)

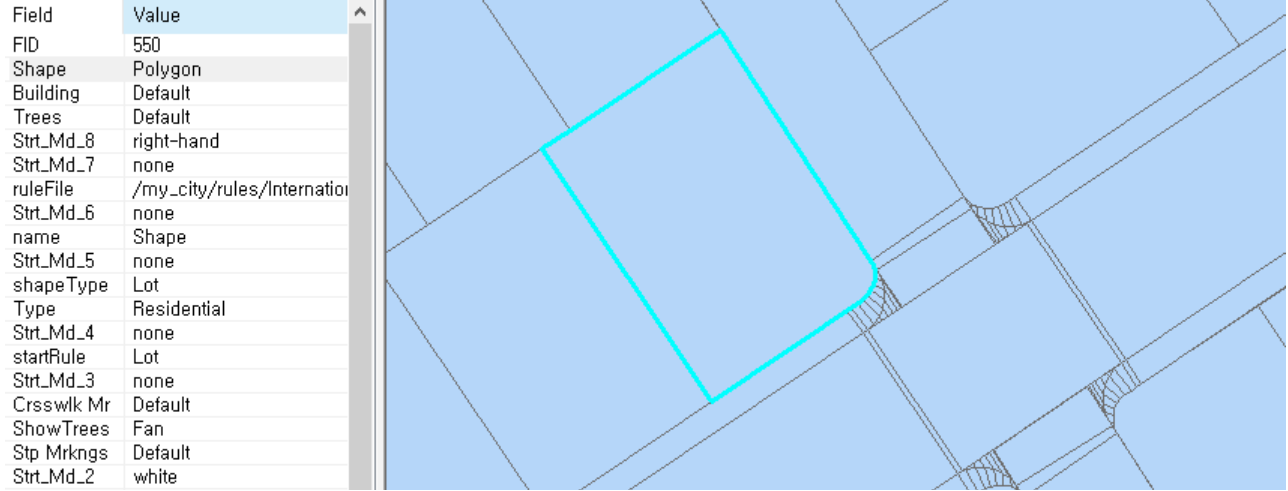

(d)

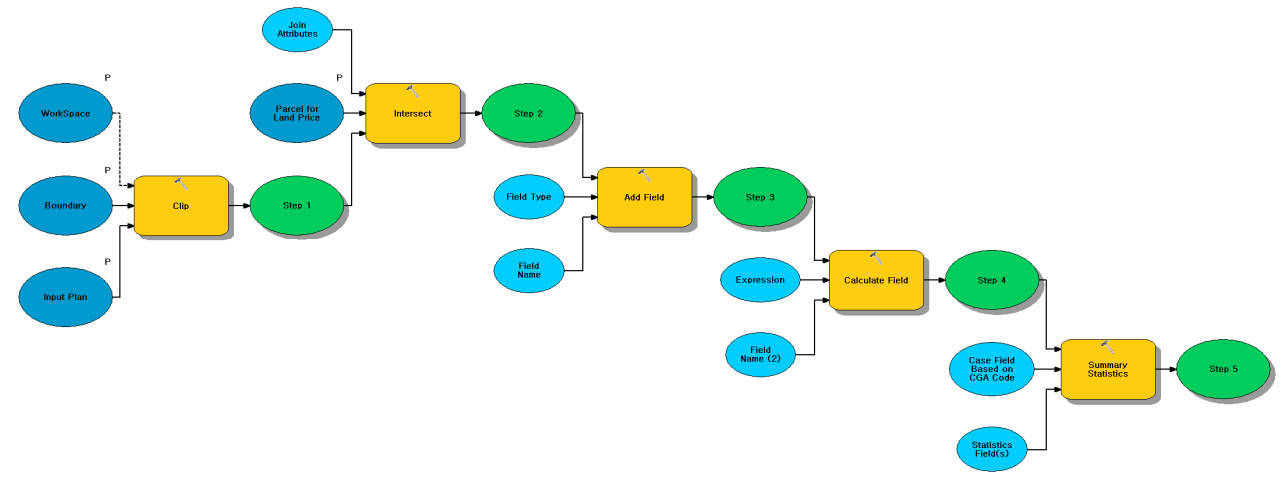

Figure 10. The process of enhancing interoperability using a rule file and spatial analysis tools: (a) prepare a variable in the rule file in CityEngine; (b) generate a model using the rule file; (c) Export the model to ArcGIS; and (d) Analyze the cost using a spatial analysis tools in ModelBuilder customized for the variable. 


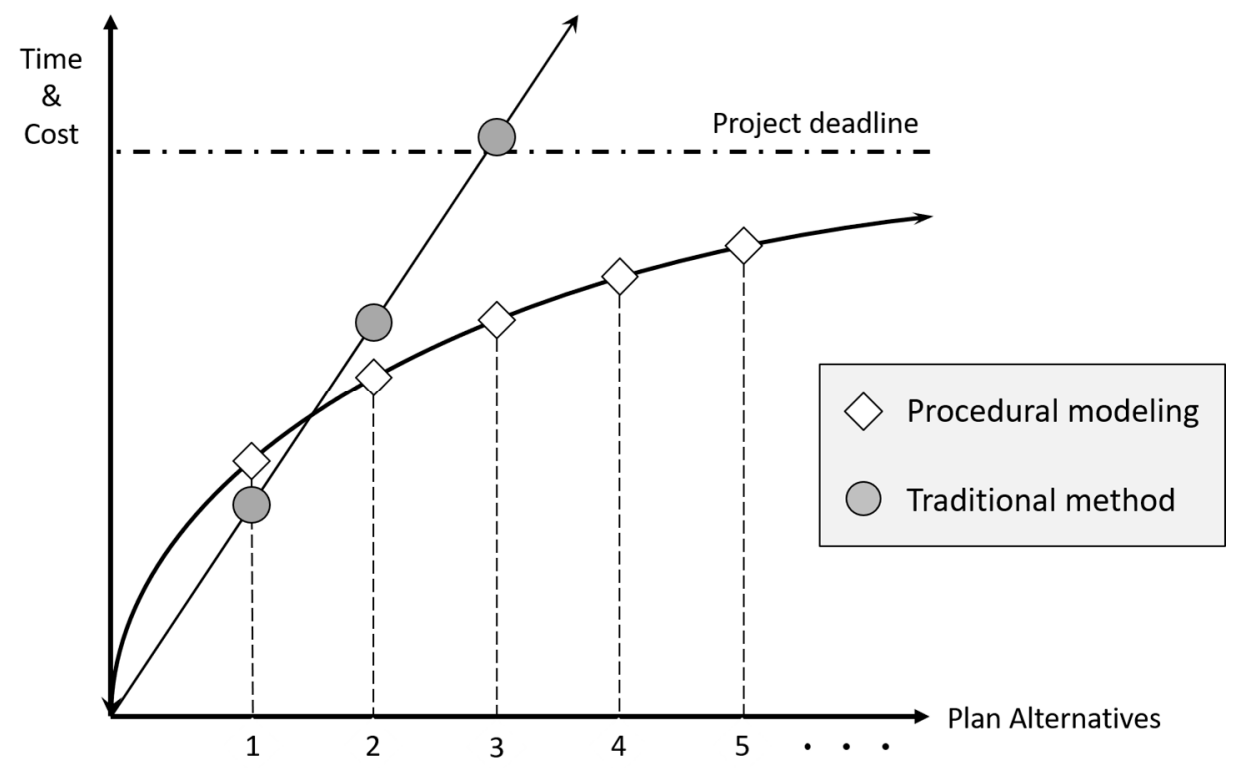

Figure 11. A comparison of the expected time and cost between the traditional method and procedural modeling.

\section{Conclusions}

The key focus of this study has been to overcome the time and cost constraints in infrastructure installation planning that hamper the efficacy of DIF in South Korea. The traditional method complicates the planning process and makes it difficult to evaluate plans. We propose procedural modeling as an alternative and have demonstrated its relative advantages, especially in enhancing workability by considerably reducing the number of steps and commands for planning practice to achieve the same outcome.

This study is not without its shortcomings. First, it compared two methods for infrastructure installation planning by reviewing each process in a relatively descriptive manner and did not incorporate a pre-defined set of quantifiable parameters, like the amount of time and cost spent on the actual work. Second, the rule file provided by the ESRI of CityEngine, which was developed mostly for a US context, was adopted in this study, instead of a customized rule file that may better account for the circumstances of Jeju. Third, the two methods were applied to a single low-density subdivision case in suburban Jeju and may require further applications in other density settings with varying housing typologies in different regions to produce more reliable outcomes.

However, this study provides several key contributions to the literature. First, this study fills existing research gaps by focusing on the applicability of the DIF in local planning practice and providing tangible solutions. Second, the research findings may be extended to the competitive local public goods equilibrium [70]. Improvements in the planning process for supplying public infrastructure may remove some sources of inefficiency.

Several policy suggestions have emerged from this study. First, financial assistance for the initial costs for preparing rule files and spatial analysis tools may help the diffusion of procedural modeling in local planning practice. Second, government-led training programs and technical support for planners will promote faster adoption of procedural modeling and lighten their burden. Third, procedural modeling may foster more efficient creation of local environmental policies on air pollution and natural open spaces to overcome the side effects of sprawl. Fourth, the findings of this study may inform the installation process of other types of infrastructure that come with new residential development, thereby reducing time and cost. Lastly, the development of manuals that ensure the interoperability of procedural modeling for the calculation of DIFs may significantly increase applicability in local planning practice. 
Author Contributions: Conceptualization, N.-Y.C.; methodology, S.K.; formal analysis, S.K.; writing-original draft preparation, N.-Y.C.; writing-review and editing, H.K.; visualization, S.K.; project administration, N.-Y.C.; funding acquisition, H.K. All authors have read and agreed to the published version of the manuscript.

Funding: This work was supported by the Ministry of Education of the Republic of Korea and the National Research Foundation of Korea (NRF-2018S1A3A2075332).

Conflicts of Interest: The authors declare no conflict of interest.

\section{References}

1. Nahrin, K. Urban development policies for the provision of utility infrastructure: A case study of Dhaka, Bangladesh. Util. Policy 2018, 54, 107-114. [CrossRef]

2. Cui, Y.; Sun, Y. Social benefit of urban infrastructure: An empirical analysis of four Chinese autonomous municipalities. Util. Policy 2019, 58, 16-26. [CrossRef]

3. Levine, J.C. Equity in Infrastructure Finance: When Are Impact Fees Justified? Land Econ. 1994, 70, $210-222$. [CrossRef]

4. Manaugh, K.; Badami, M.G.; El-Geneidy, A.M. Integrating social equity into urban transportation planning: A critical evaluation of equity objectives and measures in transportation plans in North America. Transp. Policy 2015, 37, 167-176. [CrossRef]

5. Page, S.N.; Ankner, D.W.; Jones, C.; Fetterman, R. The Risks and Rewards of Private Equity in Infrastructure. Public Works Manag. Policy 2008, 13, 100-113. [CrossRef]

6. Mullen, C. State Impact Fee Enabling Acts. In Impact Fees: Principles and Practice of Proportionate-Share Development Fees; Nelson, A.C., Nicholas, J.C., Juergensmeyer, J.C., Eds.; Routledge: New York, NY, USA, 2017.

7. Porter, D.R. Managing Growth in America's Communities: Second Edition, 2nd ed.; Island Press: Washington, DC, USA, 2012; ISBN 978-1-59726-610-9.

8. Nelson, A.C. Development impact fees. J. Am. Plan. Assoc. 1988, 54, 3-6. [CrossRef]

9. Stroud, N. Legal Considerations of Development Impact Fees. J. Am. Plan. Assoc. 1988, 54, 29-37. [CrossRef]

10. Altshuler, A.A.; Gomez-Ibanez, J.A. Regulation for Revenue: The Political Economy of Land Use Exactions; Brookings Institution Press: Washington, DC, USA, 1993; ISBN 978-0-8157-9127-0.

11. Bae, S.-S.; Kwon, S.-W.; Coutts, C.; Park, S.-C.; Feiock, R.C. Development Impact Fees: A Vehicle or Restraint for Land Development? Lex Localis 2015, 13, 1047-1065. [CrossRef]

12. Blanco, A.G.; Steiner, R.L.; Kim, J.; Chung, H. Effects of Impact Fees on Urban Form and Congestion in Florida. Transp. Res. Rec. 2012, 2297, 38-46. [CrossRef]

13. Burge, G.S.; Nelson, A.C.; Matthews, J. Effects of proportionate-share impact fees. Hous. Policy Debate 2007, 18, 679-710. [CrossRef]

14. Burge, G.S.; Ihlanfeldt, K.R. Promoting Sustainable Land Development Patterns through Impact Fee Programs. Cityscape 2013, 15, 83-105.

15. Delaney, C.J.; Smith, M.T. Pricing Implications of Development Exactions on Existing Housing Stock. Growth Chang. 1989, 20, 1-12. [CrossRef]

16. Delaney, C.J.; Smith, M.T. Impact Fees and the Price of New Housing: An Empirical Study. Real Estate Econ. 1989, 17, 41-54. [CrossRef]

17. Downing, P.B.; McCaleb, T.S. The Economics of Development Exactions; Planners Press: Chicago, IL, USA, 1987.

18. Huffman, F.E.; Nelson, A.C.; Smith, M.T.; Stegman, M.A. Who Bears the Burden of Development Impact Fees? J. Am. Plan. Assoc. 1988, 54, 49-55. [CrossRef]

19. Singell, L.D.; Lillydahl, J.H. An Empirical Examination of the Effect of Impact Fees on the Housing Market. Land Econ. 1990, 66, 82-92. [CrossRef]

20. Snyder, T.; Stegman, M.A.; Moreau, D.H. Paying for Growth: Using Development Fees to Finance Infrastructure, 3rd ed.; Urban Land Institute: Washington, DC, USA, 1989; ISBN 978-0-87420-663-0.

21. Burge, G.S.; Trosper, T.L.; Nelson, A.C.; Juergensmeyer, J.C.; Nicholas, J.C. Can Development Impact Fees Help Mitigate Urban Sprawl? J. Am. Plan. Assoc. 2013, 79, 235-248. [CrossRef]

22. Jepson, E.J. Could Impact Fees Be Used for $\mathrm{CO}_{2}$ Mitigation? J. Urban Plan. Dev. 2011, 137, 204-206. [CrossRef]

23. Nicholas, J.C.; Juergensmeyer, J.C. Market Based Approaches to Environmental Preservation: To Environmental Mitigation Fees and Beyond. Nat. Resour. J. 2003, 43, 837-863. 
24. Ahrens, A.; Lyons, S. Changes in Land Cover and Urban Sprawl in Ireland from a Comparative Perspective over 1990-2012. Land 2019, 8, 16. [CrossRef]

25. Aurambout, J.-P.; Barranco, R.; Lavalle, C. Towards a Simpler Characterization of Urban Sprawl across Urban Areas in Europe. Land 2018, 7, 33. [CrossRef]

26. DeSalvo, J.S.; Su, Q. The determinants of urban sprawl: Theory and estimation. Int. J. Urban Sci. 2019, 23, 88-104. [CrossRef]

27. Kim, H.; Kim, S.-N. Shaping suburbia: A comparison of state-led and market-led suburbs in Seoul Metropolitan Area, South Korea. Urban Des. Int. 2016, 21, 131-150. [CrossRef]

28. Kim, H.; Lee, N.; Kim, S.-N. Suburbia in evolution: Exploring polycentricity and suburban typologies in the Seoul metropolitan area, South Korea. Land Use Policy 2018, 75, 92-101. [CrossRef]

29. Kim, H.-A.; Park, S.; Kim, H.-J. A Study on Infrastructure Financing Scheme for Local Public Services: Development Impact Fee System; Korea Institute of Public Finance: Sejong, Korea, 2004.

30. Ministry of Construction and Transportation. Management Handbook for Infrastructure Rolling Systems; Ministry of Construction and Transportation: Seoul, Korea, 2004.

31. Kim, S.-J.; Park, S.-H.; Lee, J.-H. An Approach on Policy Improvement for Impact Fee Area Considering the Smart Growth; Korea Research Institute for Human Settlements: Sejong, Korea, 2010.

32. Cheoi, N.-Y. A Study on Enhancemet and Improvement of Infrastructure Bearing Area System; Ministry of Land, Infrastructure and Transport: Sejong, Korea, 2013.

33. Cheoi, N.-Y. Determination of the Impact Fee Zone Based on the Grid Analysis of Population Increase. J. Korean Assoc. Geogr. Inf. Stud. 2009, 12, 74-83.

34. Cheoi, N.-Y. A Grid Analysis to Designate the Zone to Levy the Impact Fee for Infrastructure Provision: The Case of the Industrial Localities. J. Korean Urban Geogr. Soc. 2009, 12, 65-75.

35. Cheoi, N.-Y. Spatial Designation of Impact Fee Zone based on the Parcel Development Permit Information. J. Korean Assoc. Geogr. Inf. Stud. 2009, 12, 116-127.

36. Lee, Y.J.; Cheoi, N.-Y. A Method to Use the Land-Use Zoning Information to Extract the DIF Zones. Korea Soc. Geospat. Inf. Syst. 2014, 22, 89-99.

37. Parish, Y.I.H.; Müller, P. Procedural Modeling of Cities. In Proceedings of the 28th Annual Conference on Computer Graphics and Interactive Techniques; ACM: Los Angeles, CA, USA, 2001; pp. 301-308.

38. Müller, P.; Wonka, P.; Haegler, S.; Ulmer, A.; Van Gool, L. Procedural Modeling of Buildings. In ACM SIGGRAPH 2006 Papers; ACM: New York, NY, USA, 2006; pp. 614-623.

39. Stiny, G.; Gips, J. Shape Grammars and the Generative Specification of Painting and Sculpture. In Proceedings of the IFIP Congress, Ljubljana, Yugoslavia, 23-28 August 1971; Volume 2, pp. 1460-1465.

40. Çağdaş, G. A Shape Grammar: The Language of Traditional Turkish Houses. Environ. Plan. B Plan. Des. 1996, 23, 443-464. [CrossRef]

41. Flemming, U. More Than the Sum of Parts: The Grammar of Queen Anne Houses. Environ. Plan. B Plan. Des. 1987, 14, 323-350. [CrossRef]

42. Knight, T.W. The Forty-One Steps. Environ. Plan. B Plan. Des. 1981, 8, 97-114. [CrossRef]

43. Stiny, G.; Mitchell, W.J. The Palladian Grammar. Environ. Plan. B Plan. Des. 1978, 5, 5-18. [CrossRef]

44. Wang, Y.; Duarte, J.P. Automatic generation and fabrication of designs. Autom. Constr. 2002, 11, $291-302$. [CrossRef]

45. Agarwal, M.; Cagan, J. A Blend of Different Tastes: The Language of Coffeemakers. Environ. Plan. B Plan. Des. 1998, 25, 205-226. [CrossRef]

46. Pugliese, M.J.; Cagan, J. Capturing a rebel: Modeling the Harley-Davidson brand through a motorcycle shape grammar. Res. Eng. Des. 2002,13,139-156. [CrossRef]

47. Lindenmayer, A. Mathematical models for cellular interactions in development I. Filaments with one-sided inputs. J. Theor. Biol. 1968, 18, 280-299. [CrossRef]

48. Bruneton, E.; Neyret, F. Real-Time Rendering and Editing of Vector-Based Terrains. Comput. Graph. Forum 2008, 27, 311-320. [CrossRef]

49. Hnaidi, H.; Guérin, E.; Akkouche, S.; Peytavie, A.; Galin, E. Feature based terrain generation using diffusion equation. Comput. Graph. Forum 2010, 29, 2179-2186. [CrossRef]

50. Alsweis, M.; Deussen, O. Modeling and Visualization of symmetric and asymmetric plant competition. In Proceedings of the Eurographics, Dublin, Ireland, 29 August-2 September 2005; pp. 83-88. 
51. Livny, Y.; Yan, F.; Olson, M.; Chen, B.; Zhang, H.; El-Sana, J. Automatic Reconstruction of Tree Skeletal Structures from Point Clouds. In ACM SIGGRAPH Asia 2010 Papers; ACM: New York, NY, USA, 2010; p. 151.

52. Longay, S.; Runions, A.; Boudon, F.; Prusinkiewicz, P. TreeSketch: Interactive Procedural Modeling of Trees on a Tablet. In Proceedings of the International Symposium on Sketch-Based Interfaces and Modeling, Annecy, France, 4-6 June 2012; Eurographics Association: Goslar, Germany, 2012; pp. 107-120.

53. Génevaux, J.-D.; Galin, É.; Guérin, E.; Peytavie, A.; Benes, B. Terrain Generation Using Procedural Models Based on Hydrology. ACM Trans. Graph. 2013, 32, 143. [CrossRef]

54. Huijser, R.; Dobbe, J.; Bronsvoort, W.F.; Bidarra, R. Procedural Natural Systems for Game Level Design. In Proceedings of the 2010 Brazilian Symposium on Games and Digital Entertainment, Florianopolis, Brazil, 8-10 November 2010; pp. 189-198.

55. Schwarz, M.; Müller, P. Advanced Procedural Modeling of Architecture. ACM Trans. Graph. 2015, 34, 107. [CrossRef]

56. Smelik, R.M.; Tutenel, T.; Bidarra, R.; Benes, B. A Survey on Procedural Modelling for Virtual Worlds. Comput. Graph. Forum 2014, 33, 31-50. [CrossRef]

57. Choe, H.; Tai, H.-S.; Jung, Y.; Kim, S.; Yun, S.-J.; Yoo, B.; Kim, S.; Moon, K.; Kang, K.; Kim, D.; et al. Jeju, the Island of the Commons I; Jin In Jin: Gwacheon, Korea, 2016.

58. Kwon, Y.; Kim, H.; Yoo, S. Assessment of the conservation value of Munseom area in Jeju Island, South Korea. Int. J. Sustain. Dev. World Ecol. 2018, 25, 739-746. [CrossRef]

59. Koh, E.-H.; Lee, S.H.; Kaown, D.; Moon, H.S.; Lee, E.; Lee, K.-K.; Kang, B.-R. Impacts of land use change and groundwater management on long-term nitrate-nitrogen and chloride trends in groundwater of Jeju Island, Korea. Environ. Earth Sci. 2017, 76, 176. [CrossRef]

60. Lee, J.Y.; Yang, W.J.; Jeong, H.J.; Seo, D.J.; Lee, J.C. Distribution and Pollution Assessment of River Sediments Flowing into the Jeju Coast. J. Korean Soc. Urban Environ. 2017, 17, 409-417.

61. Kam, S.; Paik, B.C.; Kim, K. A Study on the Presence of Perfluorinated Compounds (PFCs) in the Public Sewage Treatment Plants: Case of Jeju Province Sewage Treatment Plants. J. Korean Soc. Urban Environ. 2016, $16,35-45$.

62. Han, S.; Park, K. The Problem and Solution on the Chinese's Purchase of Jeju -do Real Estate. Law Policy Rev. 2015, 21, 405-437.

63. Paik, W. Chinese Investment in Foreign Real Estate and its Interactions with the Host State and Society: The Case of Jeju, South Korea. Pac. Aff. 2019, 92, 49-70. [CrossRef]

64. Yang, S.K.; Jung, W.Y.; Han, W.K.; Chung, I.M. Impact of land-use changes on stream runoff in Jeju Island, Korea. AJAR 2012, 7, 6097-6109.

65. Song, C. (Jeju Provincial Council, Jeju, South Korea). Interview. 28 March 2019.

66. Southworth, M.; Owens, P.M. The Evolving Metropolis: Studies of Community, Neighborhood, and Street Form at the Urban Edge. J. Am. Plan. Assoc. 1993, 59, 271-287. [CrossRef]

67. Benedikt, M.L. To Take Hold of Space: Isovists and Isovist Fields. Environ. Plan. B Plan. Des. 1979, 6, 47-65. [CrossRef]

68. Teklenburg, J.A.F.; Timmermans, H.J.P.; van Wagenberg, A.F. Space Syntax: Standardised Integration Measures and Some Simulations. Environ. Plan. B Plan. Des. 1993, 20, 347-357. [CrossRef]

69. Freeman, L.C. A Set of Measures of Centrality Based on Betweenness. Sociometry 1977, 40, 35-41. [CrossRef]

70. Stiglitz, J.E. The Theory of Local Public Goods Twenty-Five Years after Tiebout: A Perspective; National Bureau of Economic Research: Cambridge, MA, USA, 1982.

(C) 2020 by the authors. Licensee MDPI, Basel, Switzerland. This article is an open access article distributed under the terms and conditions of the Creative Commons Attribution (CC BY) license (http://creativecommons.org/licenses/by/4.0/). 